\title{
Store image: proposition of scale to the retail pharmaceutical segment
}

\author{
Ronaldo Barbosa de Souza ${ }^{\dagger}$ \\ Center for the Development of Fire Brigade Officers of the State of Minas Gerais \\ José Edson Lara ${ }^{\Omega}$ \\ Colleges of Pedro Leopoldo
}

SYNOPSIS: The retail pharmaceutical market, which has been gradually taking up more space in the large domestic retail segment, is characterized by a high number of sales points and an intensive market competition, developed by the big chains and small pharmacies. The latter are the majority in the universe of 59,000 pharmacies in Brazil. The former strategy of considering location as the main source of competitive advantage has been eroded in these times, and issues of store image emerge with a real possibility of differentiation to increasingly demanding customers. The aim of this study is to evaluate the impact of store image on a pharmacy. The work was developed using the clients of pharmacies in a major city in the State of Minas Gerais as the universe. Data were provided by the clients of a network of pharmacies in that municipality and, after statistical treatment, the sample data showed the importance of store image to the pharmacies. Of a total of 30 variables associated with store image, a set of nine attributes was identified to conceptually approximate the components of the marketing mix.

Keywords: Retail pharmaceutical; strategy; store image.

${ }^{\dagger}$ Master of the Novos Horizontes College of Minas Gerais

Link: Center for the Development of Fire Brigade Officers of the State of Minas Gerais Address: Rua Zurick, 826. Ap 408.Nova Suissa

- Belo Horizonte - MG - Brazil

CEP 30480-520

E-mail: isometro@terra.com.br

Telephone: (31) 25268476

\footnotetext{
${ }^{\Omega}$ Doutor em Economia da Empresa pela

Universitat Autònoma de Barcelona

Vínculo: Faculdades Pedro Leopoldo

Endereço: Rua Rodrigues Caldas, no. 475 / 402

- Bairro Santo Agostinho, Belo Horizonte - MG

- Brazil - CEP: 30.190-120

E-mail: jedson2010@ hotmail.com

Telefone: (31) 9122.6388
}

Editor's note: This paper was accepted by Antonio Lopo Martinez. 


\section{INTRODUCTION}

Martineau (1958) found that some grocery stores were getting more sales due to the fact that the shops were cleaner and whiter. Shops where customers could meet friends and where employees were more friendly held the customers' preference compared to those offering better products and services and even better prices or that had better locations. For the author, the store is not a meaningless identity whereby consumers would only follow economic rationality. The store boasted, therefore, a personality, an image, as already highlighted by Martineau about retail in his time.

Reardon, Miller and Coe (1995) consider store image as one of the main strategies that emerged in the highly competitive retail environment starting in 1990 years. The authors point out the ability to identify and, if necessary, to change the store image as a critical skill for retailers of the mentioned period.

Store image has been receiving a lot of attention by scholars focused on retailing, being the object of a special publication of the Journal of Retailing in 1974. For Reardon, Miller and Coe (1995), store image has become a strategic resource in the competitive retail market since the 1990 years. The authors, however, draw attention to the difficulty of identification and subsequent modification of a store's image. Still in the authors' perspectives, the ability to identify the significant values of store image is a critical managerial skill.

The store's theme is often studied in various types of retailers, such as restaurants by Salazar and Farias (2006). Carvalho and Motta (2002) studied services, proposing upgrading the theory of environmental psychology. Caldwell and Hibbert (2008) researched the effect of music on consumer behavior at restaurants. Farias (2007) studied the subject of atmosphere in an online store.

Cavalcanti (2007) researched the association of perceived quality with the image elements of Shopping Centers, and Spinelli and Giraldi (2004) researching the subject of store image and own brand in supermarkets. However research papers on store image of retail pharmacies are rare.

This study intends to partly fill this gap with research about the influence of store image on the clients of a network of pharmacies. It aims to identify a set of store image attributes applicable to retail pharmacies. 


\section{THEORETICAL REFERENTIAL}

Chetcohine (2000) comments that in the 1950 years, a rule of thumb for retail was location, location, and finally, location. This rule is still valid today, but it is insufficient to cope with a changing landscape marked by criticism from customers. This change demands advanced logistics, efficient cost management and competitive strategies.

The client in a point of sale goes beyond the perception of a product's tangibility . The client needs a global guarantee from the patronized point of sale. Chectochine (2000) incorporates the issues of price, quality, choice and service in this comprehensive guarantee. For the author, a customer's perception of a selling point is made up of the four components depicted in FIG. 1.

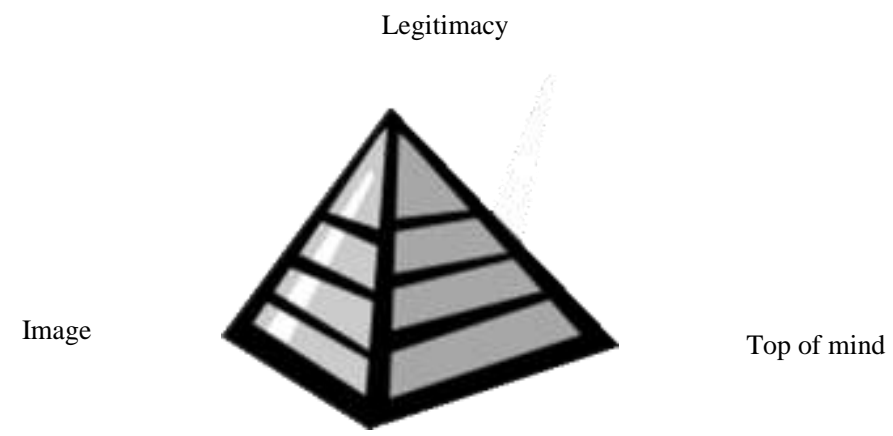

Effect of source

Figure 1: Perception of point of sale

Source: CHECTOCHINE, 2000, p.154.

Legitimacy corresponds to the notion of credibility of the point of sale. It manifests itself when the client, upon receiving a promotional brochure in his/her home, feels convinced that the retailer is able to sell the advertised products. The notion of legitimacy is closely linked to the notion of the flag's struggle for existence" (CHECTOCHINE, 2000, p. 157).

The effect of source refers to the credibility of the communication between the retailer and its customer. It is equivalent to the territory of communication granted by the client to the point of sale.

If for example in food distribution, a distributor wants to develop price operations, it is not enough just to pick some reference products and highlight them in its brochures, radio advertising or in print. It must be reliable, i.e., it must have an origin effect with respect to price (CHECTOCHINE, 2000, p. 158).

To the author Top of mind, means the relationship between the company and its rank in customers' minds in a particular purchase. In a concise form, Chetochine (2000, p. 161) 
seeks to clarify the term stating that a company's top of mind means "on whom does the client think first, where does the client go first to find this or that product, service or brand?"

The image of point of sales is built on two levels. The first level considered by the author as image perception, is the result of information received by the customer and leads the customer to classify a store as large or small, good or bad. The perception is global and not affective. The second level, called determining image, is characterized by determining the translation of feelings expressed through mechanisms of shopping perception.

Store image affects the perceived quality of a store and the consequence of a positive image causes a significant increase in the flow of customers at the points of sale. This flow of clients is considered the result of well-implemented retail marketing. Chetochine's approach on store image reveals the underlying issues of customer loyalty when he cites the customer's return to the point of sale, disregarding competitors' offers and promotions.

\footnotetext{
One of the first concerns of the retail shopper will be to focus on the shopper, and to develop marketing operations in order to get new customers to visit their points of sale or to make existing customers come back and disregard competitors' special offers and promotions (CHETOCHINE, 2000 , p.3).
}

The study of store image has aroused particular interest in recent years and especially in specialized literature. Kasulis and Lusch (1981) cite as examples the published research in this area by the Marketing Science Institute and the Journal of Retailing. One of the justifications for this interest was the evidence that the consumer market is increasingly segmented and that people organize themselves increasingly according to lifestyles. Retail managers have sought to adjust the store image to the new consumer profile.

Martineau (1958) introduced the concept of personality or store image resulting from intangible and symbolic issues. For the author, the image formation in the consumer's mind arises partly from such functional qualities as location, price, assortment, but also from psychological attributes.

The point of sale projects a personality to the consumer through its physical characteristics, through its employees, through the marketing strategy and through intangible characteristics that can not be measured directly.

The store image theme was approached by Arons (1971) in a study about the influence on store image and shopping frequency of watching television. The author indicates that the more favorable the image, the more likely the frequency of purchase. 
The definition of store image is not a simple thing, as pointed out by Burt and Carralero-Encinas (2000). According to these authors, the tangible and intangible dimensions, the complexity of meanings and the perceptions of customers in relation to retailers are recognized by the store image researchers.

Martineau's definition (1958, p.47) of store image is "the way the store is defined in the buyer's mind, partly by its functional qualities and partly by an atmosphere of psychological attributes." Macgoldrick (2002) notes that this definition is criticized by attributing a mystical character to the concept.

Doyle and Fenwick (1974) found that some of Martineau's store image examples (1958) depended on psychological aspects and defended the consumer's rational involvement with points of sales through functional multi-attributes. Bloemer and Ruyter (1998) investigated the relationship between store image, satisfaction and loyalty to the store. The research subject was the investigation of a direct relationship between store image and loyalty, or whether the relationship is indirect being mediated by satisfaction with the store.

As a research result, the hypothesis of a direct relationship between store image and loyalty was rejected and the hypothesis that satisfaction is a mediating variable between store image and loyalty was accepted. The empirical model developed by the researchers represents the relationships between image, satisfaction and loyalty. FIG. 2 presents the model.

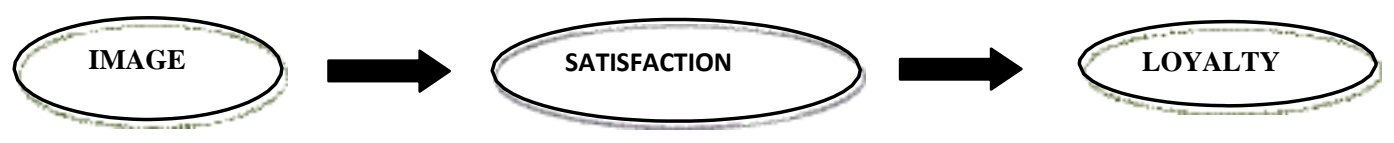

Figure 2- Relationship of store image, satisfaction and loyalty variables.

Source: BLOEMER and RUYTER, 1998. Adapted by the author.

The claim that the image of a store influences the perceived quality of products and customers' decisions are also shared by Spinelli and Giraldi (2004). The authors consider the store image probably more important to the success of a selling point than its actual characteristics.

The dominant perspective in literature, according to Bloemer and Ruyter (1998), is to treat the store image as a result of multi-attributes. The image of a store is expressed as a function of the relevant attributes of a particular store, which are evaluated and measured one by one by the consumers. 
The definition of store image, to the authors, is the sum of all the attributes of a store as perceived by customers based on their experiences with the store. The authors raised the various approaches to store image as a result of multi-attributes. Chart 1 lists the attributes of store image of each researcher.

\begin{tabular}{|l|c|}
\hline \multicolumn{1}{|c|}{ Attributes } & Author \\
\hline $\begin{array}{l}\text { Goods, services, clientele, physical facilities, convenience, promotion, store } \\
\text { atmosphere, institutional and post-sales satisfaction. }\end{array}$ & Lindquist (1974) \\
\hline Product, price, assortment, style and location. & Doyle and Fenwick (1974) \\
\hline $\begin{array}{l}\text { Price, quality of merchandise, assortment, atmosphere, location, easy to park } \\
\text { and staff involvement. }\end{array}$ & Beardem (1977) \\
\hline $\begin{array}{l}\text { Location, merchandise, store atmosphere, services for the consumer, price, } \\
\text { technical assistance (consultancy) sales staff and sales incentive programs. }\end{array}$ & Ghosh (1990) \\
\hline
\end{tabular}

\section{CHART 1 - STORE IMAGE AS A RESULT OF MULTI-ATTRIBUTES}

Source: BLOEMER E RYTER, 1998, p.502.

The components of store image are part of the image dimension to Cunha (2001) who identifies among the attributes of store image raised by Lindquist (1974) Zimmer and Golden (1998), product, pricing, promotion and location factors making up the marketing mix. The association of store image in the marketing mix is also the subject of researchers such as Kunkel and Berry (1968), May (1971). Spinelli and Giraldi (2004) detailed the attributes of store image developed by Kunkel and Berry (1968), Lindquist (1974), Doyle and Fenwick (1974).

The variety of classification and identification of the components of store image is highlighted. Macgoldrick (2002) considers the relative importance of each component of store image varying according to the markets in which the companies operate and the level of competition or even locations.

For the author, the rationale of such an effect is that different locations are likely subjected to different consumer segments that may generate different attitudes, needs and priorities.

The consumer perceives the store image through one or more attributes that he/she considers most significant or globally by the sum of all attributes (ZIMER and GOLDEM, 1998). For Cardozzo (1975), the store image is built not as a whole, but in separate attributes and that the recommended strategy for the retailer is to treat the store's image individually for each product class. 
The multi-attribute model is discussed by Levy and Weitz (2000), emphasizing the importance of the weights given by each type of user to a particular attribute or set of them. The authors provide examples reporting that, for a young single female, the most important attributes are the convenience, assortment and store atmosphere; in contrast, parents give more importance to economy, find assortment moderately important and store convenience store not very important.

Different cultural backgrounds lead to different interpretations of points of sales and of its products due to different perceptions of the point of sale's attributes. Kim and Hans (1968) showed that consumer preferences for a particular store may be linked to their cultural backgrounds which, in turn, are related to the consumers' ethnic group.

One of the components of store image present in the different academic approaches is the store's atmosphere. Fisk (1961), in his model dealing with the relationship between image and other conditions of significance to the client, presented six dimensions: convenience of location, suitability of products, value pricing, sales effort and service, friendliness of the shop and satisfaction after the transaction. The dimensions of product adequacy, sales and service efforts and friendliness of the shop approach the concept of store atmosphere.

The studies of Kunkel and Berry (1968), based on Martineau (1958) and Fisk (1961), tallied 12 components of store image. They are: price, quality, variety and freshness of products, sales staff, convenience of location, other factors of convenience, service, sales promotions, advertising, store atmosphere and reputation and adjustments. Berry (1969) confirmed the six dimensions of Fisk (1961) by increasing the dimensions of store image and kept the store atmosphere dimension.

\section{METHOD}

The present study has the characteristic of conclusive research, descriptive and yet cross-sectional. The cross-sectional feature comes from conducting a one-time data collection. In the view of Collis and Hussey (2005) the cross-sectional study is designed to obtain information on variables in different situations, but simultaneously

\subsection{Sampling Planning}

Planning a sampling exercise starts with the specification of the target population. Malhotra et al. (2006, p. 302) consider the "target population as a collection of elements holding the information sought by the researcher and about which inferences should be 
made." Aaker, Kumar and Day (2001) underscore the criticality to the survey results, of properly identifying the population and the criticality of accuracy.

For this study of pharmacy customers of the city of Téofilo Otoni, in the State of Minas Gerais were considered as the target population.

Teófilo Otoni is one of the main cities in the State of Minas Gerais and is also one of most important cities in the Northeast of the State. According to the last census of 2008, the city has 130,512 inhabitants and approximately 33 pharmacies.

The sampling unit in the concept of Malhotra et al. (2006, p.302) "is the basic unit that contains the elements of the population to be subjected to sampling.

The sample consisted of a unit of a five pharmacies of a drugstore chain based in the city for over 75 years with the feature of selling drugs and other items. The element considered by Babie (1999, p.121) "as the unit about which information is collected" for the study are the clients of these five pharmacies.

The defined sampling criterion is sampling without replacement, not probabilistic and by quota. The quota sampling is seen by Malhotra (2001) as a sample for trial in two stages. "The first stage is to develop the category of control quotas of the population elements. In the second stage elements of the sample are selected based on convenience or on judgment (MALHOTRA, 2001, p. 307).

The objective is to use the sampling by quotas as a means of ensuring that the sample composition is the same as the composition of the population by observing the characteristics of gender and time of purchase.

The choice of the gender and time of purchase variables fit the concept of sampling by trial being influenced by the researcher's experience and creativity, as noted by Malhotra (2001). The person responsible for this research has been operating for several years in the retail pharmaceutical segment, which enabled him to establish these two characteristics.

A survey conducted by POPAI in 2007, and published by Havro (2008), reveals that $65 \%$ of customers are female, and for time of purchase, $56 \%$ are concentrated in the afternoon. So the female gender quota was set at $65 \%$ of observations. For the time of purchase feature, the following values were adopted: $35 \%$ of observations for the morning, $55 \%$ for the afternoon and finally $10 \%$ for nighttime. 
Babbie (1999) draws attention to two problems of quota sampling. The first problem concerns the accuracy of the array of quotas and the second is a possible bias in the selection of the sample elements of a cell. The first problem, it is considered as bypassed due to the justification presented about the researcher's prior knowledge about the pharmaceutical retail market. Regarding the selection bias, the measure to be adopted will be the training of interviewers. It is believed that with this action, bias in sample selection can be reduced.

The sample size is the subject of study in item 3.4 of this chapter that covers the processing and statistical data analysis.

\subsection{Data Collection Technique}

The survey method was chosen as the one most suitable to obtain the information necessary for the development of a conclusive, descriptive and cross-sectional research. Malhotra (2001, p.179) defines the survey method as "a structured questionnaire given to a sample of a population and intended to elicit specific information from the respondents."

The survey method applied to this research, according to the method of application, is by personal interviews. Malhotra (2001) points out that this method is appropriate when participants need to see, touch or consume the product before the collection of information. This mode of application is suitable to the study, because information will be collected after the client has passed the pharmacy's cashier.

\subsubsection{Questionnaire development}

The importance of the questionnaire in a survey is highlighted by Babbie (1999), Malhotra (2001) and Hair et al. (2005), Hair (2005), Collis and Hussey (2005), among others. The questionnaire contains questions concerning the attributes of store image and uses it as a scale for measuring the semantic differential scale. This scale is one of the most used when attempting to measure attitudes according to Dickson and Albaum (1977), or on comparisons of brands, products, images companies in the vision of Malhotra (2001).

The questions lifted from the questionnaire of Dickson and Albaum (1977) were translated by two experienced translators who worked independently. There was no need to perform cross-translation. After the translations of the texts were compared special attention was given to the adjectives that make up each sentence of the semantic scale.

Questions from Cavalcanti (2007) dealing with store atmosphere in restaurants were added. This step resulted in the first version of the questionnaire containing 30 questions 
which were submitted for the advisor's evaluation. The second version of the questionnaire included the supervisor's comments, and after this point, we passed to the pre-test stage.

Malhotra (2001) considers that the questionnaire can best be enhanced with a pre-test. For the author, all aspects should be tested including the content of the question, the wording, sequence, format and layout, difficulties and instructions. Respondents to the pre-test must be of the same population, and the pre-test should be conducted through personal interviews.

The pre-test was conducted with 20 pharmacy clients in the study under the responsibility of the company's management. At the time of the research, besides completing the questionnaire, customers were asked about issues of statement, clearness, sequence, problems, etc. The reports from this phase led to a further revision of the questionnaire.

After the new pre-test was adopted, the footsteps of the first pretest were followed. The final questionnaire was resubmitted to the supervisor for approval.

\subsection{Processing and statistical analysis of the data}

Factor analysis was adopted to handle the objective of "to identifying and reducing the number of store image attributes applicable to the retail pharmacy segment".

Malhotra (2001) points to factor analysis as the most recommended when seeking essentially the summarization of data. For Hair et al. (2005) the primary purpose of factor analysis is to define an underlying matrix in a data grid.

The sample size should conform to the criteria recommended by Malhotra (2001) and Hair et al. (2005) of five observations per variable. Considering the survey questionnaire with 30 questions, the sample size should be of about 420 questionnaires. This number meets the criteria for conducting the factor analysis of the first two specific goals.

\section{PRESENTATION AND ANALYSIS OF RESULTS}

424 samples were collected during October and November of 2008. The number of questionnaires surpassed the mark of 420 set in the research planning stage. We used the multivariate technique of the interdependence of factor analysis to address the objective of this study which is to identify and establish a set of shop image attributes for retail pharmacies.

The initial list of attributes originated from the questions developed and answered by the customers of the pharmacies selected for the study. After examining the questionnaires, 28 
attributes of store image were obtained. Table 1 shows the attributes considered for store image. The objective is to seek common factors by using factor analysis.

Table 1- Mean and standard deviations of the store image questions

\begin{tabular}{|c|c|c|c|}
\hline Variable & Attribute & Mean & Standard Deviation \\
\hline V.1 & Store Lighting & 6.70 & 0.63 \\
\hline V.2 & Organization of shelves and gondolas & 6.33 & 1.22 \\
\hline V.3 & Product Price & 4.43 & 1.82 \\
\hline V.4 & Store Comfort & 6.41 & 1.11 \\
\hline V.5 & Number of clerks & 5.50 & 1.56 \\
\hline V.6 & Store Attractiveness & 6.25 & 1.30 \\
\hline V.7 & Discounts & 3.42 & 2.11 \\
\hline V.8 & Store Temperature & 5.20 & 1.99 \\
\hline V.9 & Product Lighting & 6.57 & 0.90 \\
\hline V.10 & Disposition of products on the shelves and gondolas & 6.23 & 1.31 \\
\hline V.11 & Number of cashiers & 4.11 & 2.12 \\
\hline V.12 & Store atmosphere & 5.47 & 1.79 \\
\hline V.13 & Noise in the shop & 6.32 & 1.36 \\
\hline V.14 & Interest in banners on prices & 5.38 & 2.06 \\
\hline V.15 & Product placement & 5.58 & 1.97 \\
\hline V.16 & Variety of brands & 6.46 & 1.18 \\
\hline V.17 & Product availability & 6.30 & 1.40 \\
\hline V.18 & Friendly staff & 6.81 & 0.75 \\
\hline V.19 & Service without pressure & 6.53 & 1.31 \\
\hline V.20 & Qualified staff & 6.51 & 1.05 \\
\hline V.21 & Store Location & 6.89 & 0.71 \\
\hline V.22 & Business hours & 2.07 & 2.22 \\
\hline V.23 & Parking options & 2.53 & 2.28 \\
\hline V.24 & Variety of services & 5.47 & 1.73 \\
\hline V.25 & Choice of payment modes & 6.61 & 1.01 \\
\hline V.26 & Store's quality of advertising & 5.36 & 2.04 \\
\hline V.27 & Friendly clients & 6.38 & 1.59 \\
\hline V.28 & Quality of products & 6.75 & 0.65 \\
\hline
\end{tabular}

Source: Research data.

Hair et al. (2005) provide some assumptions for the appropriate use of factor analysis. The authors cite the need to ensure that the data matrix has enough correlations to justify the application of factor analysis. Considering that there are 378 combinations and 272 correlations, the value of $69.3 \%$ significance at the level of 0.01 is reached. According to Hair et al. (2005) these values allow to proceed in the verification of the appropriateness of factor analysis. The next step was to compare the simple correlations with the partial correlations using the KMO test. When partial correlations are near zero, the KMO coefficient is close to 1. Malhotra (2001) considers values between 0.5 and 1 as indicative of a proper factor BBR, Braz. Bus. Rev. (Engl. ed., Online), 
analysis. A value below 0.5 indicates that the factor analysis may be inadequate. The minimum value of 0.8 is cited by Mingoti (2005) for the adequacy of factor analysis.

The Bartlett test of sphericity checks whether the correlation matrix is close or not to the identity matrix (MINGOTI, 2005). In order to use the factor analysis model, the Bartlett test should reject the null hypothesis.

H0: The correlation matrix is the identity matrix

H1: The correlation matrix is different from the identity matrix

Table 2 presents the KMO result above 0.5 and shows the p-value (significance) of Bartlett's sphericity test assuring the null hypothesis with a significance level of $5 \%$

Table 2- KMO test and Bartlett sphericity test

\begin{tabular}{c|c|c}
\hline KMO & \multicolumn{2}{c}{ Bartlett sphericity test } \\
\hline \multirow{2}{*}{0,791} & Chi-square & 3103.767 \\
& P-value & 0.000 \\
\hline
\end{tabular}

Source: SPSS ${ }^{\circledR}$ output

The anti-image correlation matrix indicates the explanatory power of the factors in each of the variables. The diagonal contains the measure of sampling adequacy for each variable, and the other values are partial correlations between variables. Like the KMO test, values above 0.5 for the entire matrix or for an individual variable show the adequacy of the factor analysis. It was found that all variables have values above 0.5 . Thus, it is not necessary to remove variables in the factor analysis model. At this point the stage of assumptions for the application of factor analysis is ended. The tests presented allow us to use factor analysis.

\subsection{Method of factor extraction}

The method defined for the extraction of factors was the method of analysis of main components analysis with correlation matrix. Hair et al. (2005, p. 99) says that the factorial model of components is appropriate "when the main concern is forecasting, or the minimum number of factors needed to explain most of the variance represented in the original set of variables."

The extraction criterion is the latent root method. The latent root technique, according to Hair et al. (2005), is the most used. The authors claim that the reasoning of the latent root criterion is that any individual value should explain the variance of at least one variable if it is to be retained for interpretation. The factors that have eigen values or latent roots greater than 1 are considered significant. The factors with the latent root or eigen value less than 1 are considered insignificant. Table 3 suggests the extraction of nine factors as the latent root 
criterion. It is observed in this table that the proportion of variance explained by these factors is poorly distributed: the first factor holds about $20 \%$ while the other factors explain less than $9 \%$ each. An orthogonal rotation is needed to better distribute the items among the factors in order to find an optimal solution.

Table 3- Initial Eigen values: store image variables

\begin{tabular}{|c|c|c|c|}
\hline \multirow{2}{*}{ Component } & \multicolumn{3}{|c|}{ Eigen Value } \\
\hline & Total & $\%$ Variance & Accumulated \% \\
\hline 1 & 5.54 & 19.77 & 19.77 \\
\hline 2 & 2.56 & 9.14 & 28.91 \\
\hline 3 & 1.57 & 5.61 & 34.53 \\
\hline 4 & 1.39 & 4.97 & 39.50 \\
\hline 5 & 1.29 & 4.60 & 44.10 \\
\hline 6 & 1.17 & 4.19 & 48.29 \\
\hline 7 & 1.10 & 3.92 & 52.21 \\
\hline 8 & 1.06 & 3.77 & 55.98 \\
\hline 9 & 1.03 & 3.68 & 59.66 \\
\hline 10 & 0.95 & 3.56 & 63.22 \\
\hline 11 & 0.91 & 3.38 & 66.60 \\
\hline 12 & 0.84 & 3.00 & 69.60 \\
\hline 13 & 0.83 & 2.95 & 72.55 \\
\hline 14 & 0.80 & 2.85 & 75.40 \\
\hline 15 & 0.74 & 2.65 & 78.05 \\
\hline 16 & 0.74 & 2.63 & 80.68 \\
\hline 17 & 0.65 & 2.34 & 83.02 \\
\hline 18 & 0.63 & 2.26 & 85.27 \\
\hline 19 & 0.60 & 2.13 & 87.41 \\
\hline 20 & 0.54 & 1.92 & 89.33 \\
\hline 21 & 0.49 & 1.73 & 91.06 \\
\hline 22 & 0.45 & 1.61 & 92.67 \\
\hline 23 & 0.43 & 1.53 & 94.20 \\
\hline 24 & 0.40 & 1.42 & 95.62 \\
\hline 25 & 0.38 & 1.36 & 96.99 \\
\hline 26 & 0.33 & 1.16 & 98.15 \\
\hline 27 & 0.27 & 0.95 & 99.10 \\
\hline 28 & 0.25 & 0.90 & 100.00 \\
\hline
\end{tabular}

Source: SPSS ${ }^{\circledR}$ output.

Table 4 refers to the array factor without rotation. The commonality is the total variance that one original variable shares with all other variables included in the analysis on the same factor. Hair et al. (2005) mention that values with commonality values smaller than 0.5 have the potential to indicate an insufficient explanation. The lowest values found in variables V.1, V.12 and V. 28, are very close to 0.5 and were kept in the un-rotated factor matrix. 
Table 4: Un-rotated factor matrix: store image variable

\begin{tabular}{|c|c|c|c|c|c|c|c|c|c|c|}
\hline Variable & $\begin{array}{c}\text { Factor } \\
1\end{array}$ & \begin{tabular}{|c|} 
Factor \\
2 \\
\end{tabular} & \begin{tabular}{|c|} 
Factor \\
$\mathbf{3}$
\end{tabular} & \begin{tabular}{|c|} 
Factor \\
4
\end{tabular} & \begin{tabular}{|c|} 
Factor \\
5
\end{tabular} & $\begin{array}{c}\text { Factor } \\
6\end{array}$ & \begin{tabular}{|c|} 
Factor \\
7
\end{tabular} & \begin{tabular}{|c|} 
Factor \\
8
\end{tabular} & $\begin{array}{c}\text { Factor } \\
9\end{array}$ & Commonalities \\
\hline V.1 & 0.46 & -0.30 & -0.26 & 0.02 & 0.10 & -0.06 & 0.30 & 0.06 & 0.00 & 0.47 \\
\hline V.2 & 0.58 & -0.45 & -0.15 & -0.11 & -0.01 & -0.05 & -0.03 & -0.02 & -0.17 & 0.61 \\
\hline V.3 & 0.33 & 0.11 & 0.27 & 0.00 & 0.49 & -0.23 & 0.13 & 0.07 & -0.24 & 0.57 \\
\hline V.4 & 0.53 & -0.15 & -0.20 & -0.29 & 0.10 & -0.05 & -0.14 & 0.18 & 0.22 & 0.54 \\
\hline V.5 & 0.51 & 0.01 & 0.09 & -0.41 & -0.14 & 0.01 & 0.17 & -0.15 & 0.04 & 0.51 \\
\hline V.6 & 0.48 & 0.15 & 0.10 & -0.23 & -0.32 & -0.03 & 0.02 & 0.12 & 0.27 & 0.50 \\
\hline V.7 & 0.49 & -0.12 & 0.35 & 0.08 & 0.28 & 0.11 & 0.24 & -0.32 & -0.06 & 0.64 \\
\hline V.8 & 0.41 & 0.03 & 0.26 & -0.14 & 0.40 & 0.01 & -0.16 & 0.07 & 0.41 & 0.62 \\
\hline V.9 & 0.51 & -0.38 & -0.09 & -0.01 & -0.01 & -0.10 & 0.25 & 0.31 & -0.10 & 0.59 \\
\hline V.10 & 0.64 & -0.45 & -0.17 & -0.09 & 0.04 & -0.09 & -0.10 & 0.13 & -0.17 & 0.71 \\
\hline V.11 & 0.42 & 0.43 & 0.35 & -0.01 & -0.17 & -0.06 & 0.12 & 0.00 & -0.12 & 0.55 \\
\hline V.12 & 0.56 & 0.13 & 0.17 & -0.15 & 0.10 & -0.04 & -0.21 & -0.06 & 0.08 & 0.45 \\
\hline V.13 & 0.44 & 0.18 & -0.03 & -0.42 & -0.08 & 0.14 & 0.22 & -0.16 & -0.24 & 0.56 \\
\hline V.14 & 0.67 & 0.01 & -0.02 & 0.15 & -0.36 & 0.16 & -0.23 & 0.10 & -0.15 & 0.71 \\
\hline V.15 & 0.65 & -0.30 & -0.05 & 0.03 & -0.02 & 0.24 & -0.17 & -0.09 & -0.22 & 0.66 \\
\hline V.16 & 0.46 & 0.36 & -0.39 & 0.32 & 0.02 & -0.34 & -0.12 & -0.14 & -0.10 & 0.76 \\
\hline V.17 & 0.47 & 0.42 & -0.29 & 0.34 & 0.15 & -0.24 & -0.14 & -0.22 & -0.08 & 0.75 \\
\hline V.18 & 0.29 & 0.39 & -0.04 & -0.17 & 0.11 & -0.20 & 0.10 & -0.43 & 0.12 & 0.52 \\
\hline V.19 & 0.22 & 0.37 & -0.41 & -0.04 & 0.29 & 0.26 & -0.13 & 0.25 & 0.24 & 0.63 \\
\hline V.20 & 0.53 & 0.30 & -0.05 & 0.08 & -0.05 & 0.03 & -0.13 & 0.10 & 0.28 & 0.50 \\
\hline V.21 & 0.17 & 0.17 & -0.12 & 0.10 & 0.10 & 0.76 & 0.10 & -0.17 & 0.03 & 0.71 \\
\hline V.22 & 0.09 & -0.47 & 0.44 & 0.13 & -0.13 & -0.09 & -0.24 & -0.30 & 0.25 & 0.67 \\
\hline V.23 & -0.09 & 0.30 & 0.41 & -0.02 & 0.23 & -0.09 & 0.03 & 0.47 & -0.16 & 0.57 \\
\hline V.24 & 0.40 & -0.27 & 0.24 & 0.34 & 0.25 & 0.20 & -0.01 & 0.06 & 0.03 & 0.52 \\
\hline V.25 & 0.28 & 0.14 & 0.00 & 0.48 & -0.04 & 0.11 & 0.47 & 0.11 & 0.12 & 0.60 \\
\hline V.26 & 0.46 & 0.10 & 0.34 & 0.33 & -0.28 & 0.03 & -0.27 & 0.10 & -0.09 & 0.62 \\
\hline V.27 & 0.25 & 0.60 & 0.14 & -0.15 & -0.27 & 0.05 & 0.08 & 0.14 & -0.12 & 0.57 \\
\hline V.28 & 0.28 & -0.22 & -0.04 & 0.21 & -0.27 & -0.21 & 0.40 & 0.02 & 0.41 & 0.47 \\
\hline Eigen values & 5.54 & 2.56 & 1.57 & 1.39 & 1.29 & 1.17 & 1.10 & 1.06 & 1.03 & 16.70 \\
\hline$\%$ variation & 19.77 & 9.14 & 5.62 & 4.97 & 4.60 & 4.19 & 3.92 & 3.77 & 3.68 & 59.66 \\
\hline
\end{tabular}

Source: SPSS ${ }^{\circledR}$ output.

\subsection{Rotation of factors}

In a rotation of factors, the reference axes are rotated around the origin until a new position is reached. For Hair et al. (2005, p. 104), "the final effect of rotating the factor matrix is to redistribute the variance of the factors in the past in order to achieve a standard factorial that is simpler and theoretically more significant."

The orthogonal rotation, in the view of Mingoti (2005), preserves the original orientation among the factors keeping them at right angles after rotation. The criterion adopted for the orthogonal rotation is the varimax which is concentrated in the simplification 
of the columns of the matrix of factors. Table. 5 shows the matrix of factors after the varimax orthogonal rotation. Notice the better distribution of the variables in the factors. The total amount of variance extracted by the factor solution does not change with rotation. The percentage of the total variance being explained in each factor has changed after the rotation. The factor 1 before rotation explained $19.8 \%$ of the total variation and after rotation this value decreased to $12.3 \%$, representing an improvement in the model.

Table 5: Rotated factor matrix: store image variables

\begin{tabular}{|c|c|c|c|c|c|c|c|c|c|}
\hline Variable & $\begin{array}{c}\text { Factor } \\
1 \\
\end{array}$ & $\begin{array}{c}\text { Factor } \\
2 \\
\end{array}$ & $\begin{array}{c}\text { Factor } \\
\mathbf{3} \\
\end{array}$ & $\begin{array}{c}\text { Factor } \\
4 \\
\end{array}$ & $\begin{array}{c}\text { Factor } \\
5 \\
\end{array}$ & $\begin{array}{c}\text { Factor } \\
6 \\
\end{array}$ & \begin{tabular}{|c|} 
Factor \\
7 \\
\end{tabular} & $\begin{array}{c}\text { Factor } \\
8 \\
\end{array}$ & $\begin{array}{c}\text { Factor } \\
9 \\
\end{array}$ \\
\hline V.1 & 0.57 & 0.07 & -0.13 & 0.10 & 0.06 & -0.04 & 0.04 & 0.06 & 0.31 \\
\hline V.2 & 0.75 & 0.12 & 0.06 & 0.07 & 0.05 & 0.15 & -0.04 & 0.00 & -0.02 \\
\hline V.3 & 0.17 & 0.12 & -0.04 & 0.20 & 0.09 & 0.05 & -0.02 & -0.02 & 0.69 \\
\hline V.4 & 0.49 & 0.14 & 0.01 & 0.05 & 0.51 & -0.09 & -0.07 & -0.08 & -0.01 \\
\hline V.5 & 0.29 & 0.62 & 0.07 & -0.03 & 0.18 & 0.08 & -0.02 & 0.01 & 0.06 \\
\hline V.6 & 0.12 & 0.42 & 0.33 & -0.04 & 0.36 & -0.03 & -0.12 & -0.12 & 0.21 \\
\hline V.7 & 0.25 & 0.29 & -0.01 & 0.11 & 0.06 & 0.43 & 0.38 & 0.35 & 0.15 \\
\hline V.8 & 0.09 & 0.09 & 0.00 & 0.01 & 0.70 & 0.20 & 0.27 & 0.07 & 0.01 \\
\hline V.9 & 0.67 & 0.05 & 0.08 & -0.08 & 0.04 & -0.07 & 0.15 & -0.08 & 0.30 \\
\hline V.10 & 0.81 & 0.04 & 0.13 & 0.08 & 0.13 & 0.08 & 0.03 & -0.05 & -0.03 \\
\hline V.11 & -0.08 & 0.47 & 0.44 & 0.15 & 0.03 & -0.01 & 0.29 & 0.00 & 0.13 \\
\hline V.12 & 0.21 & 0.30 & 0.24 & 0.19 & 0.40 & 0.15 & 0.16 & 0.03 & -0.10 \\
\hline V.13 & 0.25 & 0.66 & 0.04 & 0.05 & -0.02 & -0.13 & 0.06 & 0.17 & -0.08 \\
\hline V.14 & 0.42 & 0.15 & 0.66 & 0.17 & 0.08 & 0.00 & -0.12 & 0.14 & 0.03 \\
\hline V.15 & 0.64 & 0.11 & 0.29 & 0.11 & 0.07 & 0.18 & -0.02 & 0.31 & -0.12 \\
\hline V.16 & 0.16 & 0.04 & 0.19 & 0.81 & 0.04 & -0.15 & 0.00 & -0.07 & 0.10 \\
\hline V.17 & 0.08 & 0.05 & 0.17 & 0.82 & 0.10 & -0.07 & 0.09 & 0.08 & 0.04 \\
\hline V.18 & -0.12 & 0.49 & -0.14 & 0.18 & 0.45 & 0.09 & 0.04 & 0.01 & 0.02 \\
\hline V.19 & 0.02 & -0.06 & -0.02 & 0.22 & 0.50 & -0.50 & -0.04 & 0.28 & -0.03 \\
\hline V.20 & 0.08 & 0.16 & 0.35 & 0.28 & 0.46 & -0.09 & -0.02 & 0.09 & 0.18 \\
\hline V.21 & -0.03 & 0.11 & 0.06 & -0.01 & 0.07 & -0.12 & 0.81 & -0.11 & 0.02 \\
\hline V.22 & 0.07 & -0.10 & 0.13 & -0.14 & 0.10 & 0.77 & -0.10 & -0.09 & 0.02 \\
\hline V.23 & -0.23 & -0.05 & 0.19 & -0.19 & 0.08 & -0.23 & 0.60 & -0.15 & -0.05 \\
\hline V.24 & 0.31 & -0.20 & 0.18 & -0.01 & 0.16 & 0.30 & 0.29 & 0.34 & 0.18 \\
\hline V.25 & 0.02 & -0.02 & 0.17 & 0.16 & -0.05 & -0.09 & 0.16 & 0.65 & 0.28 \\
\hline V.26 & 0.10 & 0.00 & 0.73 & 0.13 & 0.07 & 0.21 & 0.11 & 0.04 & 0.07 \\
\hline V.27 & -0.21 & 0.47 & 0.42 & 0.08 & 0.04 & -0.32 & 0.12 & -0.01 & 0.04 \\
\hline V.28 & 0.19 & 0.06 & 0.02 & 0.02 & 0.08 & 0.17 & -0.17 & -0.16 & 0.70 \\
\hline Eigen values & 3.44 & 2.04 & 1.97 & 1.96 & 1.68 & 1.58 & 1.43 & 1.31 & 1.30 \\
\hline$\%$ variation & 12.28 & 7.29 & 7.04 & 6.99 & 6.00 & 5.63 & 5.11 & 4.66 & 4.66 \\
\hline
\end{tabular}


The model solution shows that $60 \%$ of the total variance is represented by the information contained in the factor array in terms of nine factors. This index is considered appropriate and this figure states that the variables are closely related to each other.

The commonalities presented show that three variables (V.4, V.5, V.28) have values below 0.5. Hair et al. (2005) recommend the following actions when the commonalities are very low. One option is to interpret the solution as it presents itself and ignore the variable. Another option is to evaluate the possibility of eliminating the variable. By observing the three variables and proving the closeness of their values with a limit of 0.5 it was decided to keep them in the model.

\subsection{Naming the factors}

Factor 1 is composed of the attributes of store lighting, organization of shelves and gondolas, store comfort, product lighting, arrangement of products on shelves and gondolas, and product placement. All these attributes fit completely in the component of store atmosphere used in the questionnaire's assembly. Of the 11 attributes of store atmosphere extracted from Dickson and Albaum (1977), Cavalcanti (2007), six attributes fit in factor 1, named store atmosphere.

Factor 2 consists of the attributes number of clerks, store attractiveness, number of cashiers, noise in the shop and friendly customers. This factor was named involvement.

Factor 3 consists of the attributes concerning product price and the attractiveness of advertising by the store. The two factors are close to the advertising attribute cited by Kunkel and Berry (1968) as one of 12 components of store image. Factor 3 was named store advertising.

Factor 4 consists of the attributes related to variety of brands and product availability. This factor is labeled assortment. The assortment attribute is cited by Beard (1977) as one of the seven attributes of store image.

Factor 5 consists of the attributes related to friendly clerks, staff qualification and store atmosphere. Factor 5 is named service.

Factor 6 consists of price discount, service without pressure and business hours. Factor 6 is named sales incentives.

Factor 7 consists of parking options and attributes of store location. This factor is named convenience of location. Beard (1977) separates parking from location as attributes, 
but the two attributes as a single factor were close to the approach of Kunkel and Berry (1968) mentioning the attribute of convenience of the location.

Factor 8 consists of the attributes range of services and payment options. Factor 8 is named consumer services.

Factor 9 consists of the attributes product price and product quality. Factor 9 was named product.

\section{CONCLUSIONS}

The overall objective of this study was to identify and analyze a set of attributes of store environment, applicable to a pharmacy. To reach our objective, we sought, through theoretical research, a research model that portrays the issues of store image. For this research, we opted for the use of questionnaires to interview 423 clients of a network of pharmacies located in the city of Teofilo Ottoni, State of Minas Gerais.

The application of factor analysis for the group of 28 variables extracted from the theoretical framework resulted in a model of store image attributes with nine dimensions: store atmosphere, involvement, advertising, assortment, customer service, sales incentives, convenience of location, consumer services and product.

The components surveyed by the research do not quite fit the attributes considered by Lindquist (1974), Doyle and Fenwick (1974), Beard (1977), Ghosh (1990). This discrepancy is provided by Macgoldrick (2002) who considers the variety of component classification of store image which the relative importance of each market where the companies operate.

The component of store atmosphere, present in most studies of image, was considered one of the components applicable to a pharmacy. The nine components of store image are close to the marketing mix and this approach is foreseen by Kunkel and Berry (1968) and Macgoldrick (2002).

We recommended to extend the research of store image to the types of products (drugs and other products) of a pharmacy. Cardozzo (1975) considers that the most recommended strategy is to treat the store image individually for each product class.

The proper management of store image is considered a great managerial challenge and the study conclusions point out that this challenge extends to retail pharmacies. Below are some managerial implications for the pharmacy work extracted from the study. 
a) using a set of store image attributes as a way of gaining competitive advantage over competitors;

b) segmentation of the pharmacy into three groups of customers;

c) using a set of store atmosphere attributes for each group of drug customers.

\section{REFERENCES}

AAKER, D. A; KUMAR, V; DAY, G. S. Pesquisa de marketing (Marketing research). São Paulo: Atlas, 2001.

BABBIE, E. Métodos de pesquisa survey. (Survey research methods) Belo Horizonte:Editora UFMG,1999.

BEARDEN, W.O. Determinant attributes of store patronage: downtown versus outlying shopping areas. Journal of Retailing, v. 53, p. 15-22, 1977.

BERRY, L. The components of department store image: a theoretical and empirical analysis. Journal of Retailling, v. 45, n.1, 1969.

BLOEMER, J; RYTER, K. On the relationship between store image, store satisfaction and store loyalty. European Journal of Marketing, West Yorkshire: MCB Publications, v. 32, n. 5/6, p. 499-513,1998.

BURT, S.; CARRALERO-ENCINAS, J. The role of store image in retail

internationalization. International Marketing Review. v. 17,n.4/5, p. 433-453, 2000.

CALDWELL, C.; HIBBERT, S. A. Play that again: The effect of music on consumer behavior in a restaurant. Available at: <http://www.acrwebsite.org/fop/websites.asp?vis=4>. Accessed: 12 Feb. 2008.

CARDOZZO, R.N. How images vary by product class- a psycholinguistic approach to store image measurement. Journal of Retailing, v.50, n.4, p.85-98, Winter, 1975.

CARVALHO, J. L. F.S.; MOTTA, P. C. Experiências em cenários temáticos de serviços (Experiences in themed services). Revista de Administração de Empresas - RAE (Journal of Business Administration - RAE) . São Paulo, v. 42, n. 2, p. 54-65, Apr. /Jun. 2002

CAVALCANTI, G. G. Elementos de imagem e qualidade percebida : a perspectiva dramatúrgica do marketing de serviços em shopping centers. (Elements of image and perceived quality: a dramaturgical perspective of services marketing at the mall) $2007.123 \mathrm{f}$. Dissertation (Master in administration), Universidade Federal de Pernambuco, Recife, 2007.

CHETOCHINE, G. Marketing estratégico da distribuição. (Strategic marketing, distribution) São Paulo: Makron Books, 2000.

COLLIS, J; HUSSEY, R. Pesquisa em administração (Research in Administration). Porto Alegre: Bookmam, 2005. 
CUNHA, F. A avaliação da imagem percebida de três hipermercados junto a consumidores da grande São Paulo.(The evaluation of the perceived image of three hypermarkets with consumers of Greater Sao Paulo) 2001.205 f. Dissertation (Master in Economics), Universidade de São Paulo, São Paulo, 2001.

DICKSON, J; ALBAUM, G. A method for developing tailormade semantic differential for specific marketing content areas. Journal of marketing research, v.14, p. 87-91, 1977.

DOYLE, P.; FENWICK, I. "How store image affects shopping habits in grocery chains. Journal of Retailing, New York, v. 50, n.4, p. 39-52, 1974.

FARIAS, S. Atmosfera de loja on-line: o impacto do ambiente virtual na satisfação do consumidor e na atitude de compra (Online store atmosphere: the impact of the virtual environment on customer satisfaction and attitude of purchase). Journal of Business-RAE, São Paulo, v.42, n.1, p.31-41, Jan / Feb). Revista de Administração de Empresas-RAE (Journal of Business-RAE), São Paulo, v.42, n.1, p.31-41, jan./fev./mar. 2007.

FISK, G. A conceptual model for studying customer image. Journal of retailing, v. 37, n.4, 1961.

GHOSH, A. Retail management. Chicago: The Dryden Press, 1990.

HAIR, J. F. et al. Análise multivariada de dados (Multivariate analysis). Porto Alegre: Bookman, 2005.

HAVRO, A. O comportamento do consumidor em farmácias e drogarias (Consumer behavior in pharmacies). Avaliable at: $<$ http://www.andrehavro.com/2007/11/05/ocomportamento-do-consumidor-em-farmacias-e-drogarias/>. Accessed: 08 Sep. 2008.

KASULIS, J. J.; LUSCH, R. F. Validating the retail store image concept. Journal of the Academy of Marketing Science, v. 9, n. 4, p. 419-435, 1981.

KIM, Y.; HANS, S. Perceived images of retail stores: comparison among three ethnic consumer groups. Journal of family and Consumer Sciences, Alexandria, v. 32, n.4, p.2127. 1968.

KUNKEL, J. H.; BERRY, L. L. A behavioral conception of retail image. Journal of Marketing, v. 32, n.4. 1968.

LEVY, M.; WEITZ, B. A. Administração de varejo (Retail management). São Paulo: Atlas, 2000.

LINDQUIST, J. D. Meaning of image: a survey of empirical and hypothetical evidence. Journal of Retailing, v. 50, n. 4, p. 29-38, 1974.

MALHOTRA, N. Pesquisa de marketing (Marketing research). Porto Alegre: Bookman, 2001.

MALHOTRA, N.et al. Introdução à pesquisa de marketing (Introduction to marketing research). São Paulo: Prentice Hall, 2006. 
MARTINEAU, P. The personality of the retail store. Harvard Business Review, v. 36. 1958.

McGOLDRICK, P. J. Retail Marketing. London: McGraw-Hill, 2002.

McGOLDRICK, P. J. In: BAKER, M. J. Administração de marketing (Marketing Management). Rio de Janeiro: Elsevier, 2005. p. 553- 573.

MINGOTI, S. A. Análise de dados através de métodos de estatística multivariada: uma abordagem aplicada (Analysis of data by multivariate analysis: an applied approach). Belo Horizonte: Editora UFMG, 2005.

REARDON, J.;MILLER,C. E.; COE, B. Applied scale development: measurement of store image. Journal of Applied Business Research. v.11, n.4, p.85-93, 1995.

SALAZAR, V.; FARIAS, S. Atmosfera de serviços em restaurantes gastronômicos: influencias hedônicas na satisfação do consumidor (Service atmoshphere in gourmet restaurants: hedonic influences on consumer satisfaction). In: Encontro Anual da Associação Nacional dos Programas de Pós Graduação em administração (Annual Meeting of the National Association of Graduate Programs in Administration). 30., 2006. Campinas. annals Campinas: ANPAD, 2006.

ZIMMER, M.; GOLDEN, L.L. Impressions of retail stores: a content analysis of consumer images. Journal of retailing, v. 64, n.3, p. 265-293, Fall, 1998. 